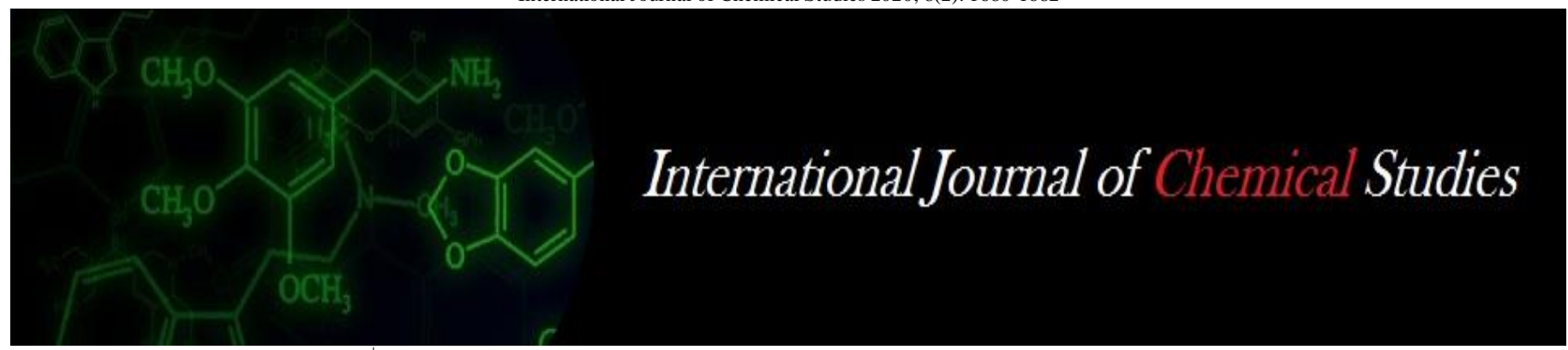

P-ISSN: 2349-8528

E-ISSN: 2321-4902

www.chemijournal.com

IJCS 2020; 8(2): 1680-1682

(C) 2020 IJCS

Received: 16-01-2020

Accepted: 18-02-2020

Ruchika S Nagmote

PG students of Soil Science \&

Agricultural Chemistry, College

of Agriculture, Nagpur,

Maharashtra, India

Ommala D Kuchanwar

Associate Professor of Soil

Science \& Agricultural

Chemistry, College of

Agriculture, Nagpur,

Maharashtra, India

Neha K Chopde

Associate Professor of

Horticulture, College of

Agriculture, Sonapur,

Gadchiroli, Maharashtra, India

Padmaja H Kausadikar

Assistant Professor of Soil

Science \& Agricultural

Chemistry, College of

Agriculture, Nagpur,

Maharashtra, India

Kirtimala R Gopal

Assistant Professor of Botany,

Institute of Science, Nagpur,

Maharashtra, India

PA Panghate

PG students of Soil Science \&

Agricultural Chemistry, College of Agriculture, Nagpur,

Maharashtra, India

Corresponding Author: Ommala D Kuchanwar Associate Professor of Soil Science \& Agricultural Chemistry, College of Agriculture, Nagpur, Maharashtra, India

\section{Effect of graded level of nitrogen and phosphorus on yield, quality and total uptake of calendula}

\author{
Ruchika S Nagmote, Ommala D Kuchanwar, Neha K Chopde, Padmaja H \\ Kausadikar, Kirtimala R Gopal and PA Panghate
}

DOI: $\underline{\text { https://doi.org/10.22271/chemi.2020.v8.i2z.9003 }}$

\begin{abstract}
This research was conducted to investigate the effect of graded level of $\mathrm{N}$ and $\mathrm{P}$ on yield, quality and uptake of calendula, during winter season at Horticulture Section, College of Agriculture, Nagpur. Using different levels and combination of nitrogen and phosphorus for evaluate the yield, quality and uptake of calendula. The Experiment was laid out in factorial in randomized block design with sixteen treatments (each treatment with 3 replications). The results of present investigation revealed that, application of 100 $\mathrm{kg} \mathrm{ha}^{-1} \mathrm{~N}$ and $50 \mathrm{~kg} \mathrm{ha}^{-1} \mathrm{P}$ produced significantly maximum shelf life, vase life of flower and oil content in flower with respect to quality parameters which were at par with the results obtained with the application of $125 \mathrm{~kg} \mathrm{ha}^{-1} \mathrm{~N}$ and $75 \mathrm{~kg} \mathrm{ha}^{-1} \mathrm{P}$. Total uptake of nitrogen, phosphorus, potassium in flower and plant of calendula maximum in treatment combination $\mathrm{N}_{3} \mathrm{P}_{3}$ i.e. $125 \mathrm{~kg} \mathrm{ha}^{-1} \mathrm{~N}$ and $75 \mathrm{~kg} \mathrm{ha}^{-1} \mathrm{P}$. The interaction effects revealed that, they were significant in respect to number of flowers plant ${ }^{-1}$, flower yield q ha ${ }^{-1}$, oil content in flower and total NPK uptake of calendula. For these parameters, the best treatment combination was $100 \mathrm{~kg} \mathrm{~N} \mathrm{~kg} \mathrm{ha}^{-1}+50 \mathrm{P} \mathrm{kg} \mathrm{ha}^{-1}$ and $125 \mathrm{~N} \mathrm{~kg} \mathrm{ha}^{-1}+75 \mathrm{P} \mathrm{kg} \mathrm{ha}^{-1}$.
\end{abstract}

Keywords: Calendula, Nitrogen, Phosphorus, yield, quality, uptake

\section{Introduction}

Calendula is very important ornamental plant which growing as winter annual for landscaping. It belongs to family, Compositeae. It is considered as a valuable medicinal plant which contains oleanolic acid and other compounds, which have considerable interest for potential health benefits, including protective effects against development of cancer, inhibition of existing tumour cells, protection against several diseases (Dharmananda and Subhuti, 2003). Pigment of calendula flower is used in food colouring. It has a long flowering period bearing large yellow or orange single or double flowers with many petals. This hardy annual prefers well drained, light and sandy soil and grows to a height on about 21-65 cm. Nitrogen and phosphorus are essential nutrients for any plant growth. These nutrients are sometime deficient in soil which fulfilled by application of fertilizers based on soil analysis and crop requirement. Nitrogen is responsible for synthesis of protein, amino acids, nucleic acids, chlorophyll and protoplasm of cell which help in harvesting solar energy through chlorophyll compounds. Phosphorus is a structural component of the cell constituent. Phosphorus plays a vital role in photosynthesis, respiration, energy storage and cell division. It promotes early root formation and growth. Phosphorus improves the quality of flower. It also brings early seed formation by stimulating early flowering.

\section{Material and methods}

The present investigation was carried out at Horticulture section, Nagpur during October 2018 to March 2019 to study the effect of graded level of $\mathrm{N}$ and P on growth, flower, yield and quality of calendula. The research was carried out on the local variety. Sixteen treatment combinations with four levels of $50,75,100,125 \mathrm{~kg} \mathrm{ha}^{-1}$ and phosphorus $0,25,50$ and $75 \mathrm{~kg}$ $\mathrm{ha}^{-1}$ were tested in factorial randomized block design with three replications. The different combinations of nitrogen and phosphorus as : $\mathrm{T}_{1}-0 \mathrm{~kg} \mathrm{~N} \mathrm{ha}{ }^{-1}+0 \mathrm{~kg} \mathrm{Pha}^{-1}\left(\mathrm{~N}_{0} \mathrm{P}_{0}\right), \mathrm{T}_{2}-0 \mathrm{~kg}$ $\mathrm{N} \mathrm{ha}^{-1}+25 \mathrm{~kg} \mathrm{Pha}^{-1}\left(\mathrm{~N}_{0} \mathrm{P}_{1}\right), \mathrm{T}_{3}-0 \mathrm{~kg} \mathrm{~N} \mathrm{ha}^{-1}+50 \mathrm{~kg} \mathrm{Pha}^{-1}\left(\mathrm{~N}_{0} \mathrm{P}_{2}\right), \mathrm{T}_{4}-0 \mathrm{~kg} \mathrm{~N}^{-1}+75 \mathrm{~kg} \mathrm{P}$

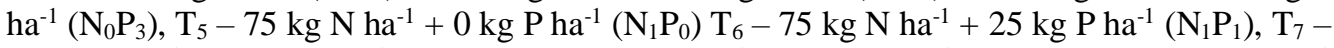
$75 \mathrm{~kg} \mathrm{~N} \mathrm{ha}^{-1}+50 \mathrm{~kg} \mathrm{Pha}{ }^{-1}\left(\mathrm{~N}_{1} \mathrm{P}_{2}\right), \mathrm{T}_{8}-75 \mathrm{~kg} \mathrm{~N} \mathrm{ha}^{-1}+75 \mathrm{~kg} \mathrm{Pha}^{-1}\left(\mathrm{~N}_{1} \mathrm{P}_{3}\right), \mathrm{T}_{9}-100 \mathrm{~kg} \mathrm{~N} \mathrm{ha}^{-1}$ 
$+0 \mathrm{~kg} \mathrm{Pha}^{-1}\left(\mathrm{~N}_{2} \mathrm{P}_{0}\right), \mathrm{T}_{10^{-}} 100 \mathrm{~kg} \mathrm{~N} \mathrm{ha}^{-1}+25 \mathrm{~kg} \mathrm{P}^{-1}\left(\mathrm{~N}_{2} \mathrm{P}_{1}\right)$, $\mathrm{T}_{11}-100 \mathrm{~kg} \mathrm{~N} \mathrm{ha}^{-1}+50 \mathrm{~kg} \mathrm{P} \mathrm{ha}^{-1}\left(\mathrm{~N}_{2} \mathrm{P}_{2}\right) \mathrm{T}_{12}-100 \mathrm{~kg} \mathrm{~N} \mathrm{ha}^{-1}+$ $75 \mathrm{~kg} \mathrm{P} \mathrm{ha}^{-1}\left(\mathrm{~N}_{2} \mathrm{P}_{3}\right), \mathrm{T}_{13}-125 \mathrm{~kg} \mathrm{~N} \mathrm{ha}^{-1}+0 \mathrm{~kg} \mathrm{P} \mathrm{ha}^{-1}\left(\mathrm{~N}_{3} \mathrm{P}_{0}\right)$, $\mathrm{T}_{14}-125 \mathrm{~kg} \mathrm{~N} \mathrm{ha}^{-1}+25 \mathrm{~kg} \mathrm{P} \mathrm{ha}^{-1}\left(\mathrm{~N}_{3} \mathrm{P}_{1}\right), \mathrm{T}_{15}-125 \mathrm{~kg} \mathrm{~N} \mathrm{ha}^{-1}+$ $50 \mathrm{~kg} \mathrm{P} \mathrm{ha}{ }^{-1}\left(\mathrm{~N}_{3} \mathrm{P}_{2}\right)$ and $\mathrm{T}_{16}-125 \mathrm{~kg} \mathrm{~N} \mathrm{ha}^{-1}+75 \mathrm{~kg} \mathrm{P} \mathrm{ha}^{-1}$ $\left(\mathrm{N}_{3} \mathrm{P}_{3}\right)$. The seeds of calendula were sown in the nursery beds in the month of October, 2018. Calendula seedlings of uniform size were transplanted 15 days after sowing at the spacing of $30 \mathrm{~cm} \times 30 \mathrm{~cm}$ in the month of October, 2018. Full doses of nitrogen and phosphorus as per the treatments and recommended dose of $50 \mathrm{~kg} \mathrm{~K} \mathrm{~kg} \mathrm{ha}^{-1}$ were applied at the time of transplanting.

Package of practices including irrigation were adopted as per recommendation. Five plants were selected randomly from each plot for recording various yield parameters i.e., number of flowers plant ${ }^{-1}$, flower yield $\mathrm{q} \mathrm{ha}{ }^{-1}$, shelf life, vase life of flower and oil content in flower with respect to quality parameters and total uptake of NPK by calendula were recorded on these randomly selected plants. Data were statistically analysed in FRBD (Panse and Sukhatme, 1967) [5].

\section{Results and discussion}

The data presented in table 1, 2 and 3 revealed that, different levels of nitrogen and phosphorus had significant effect on all growth, flowering, yield and quality parameters of calendula.

Table 1: Effect of graded level of $\mathrm{N}$ and $\mathrm{P}$ on number of flowers plant ${ }^{-1}$, flower yield $\mathrm{q}$ ha $^{-1}$ of calendula

\begin{tabular}{|c|c|c|c|c|c|c|c|c|c|c|}
\hline Treatment & \multicolumn{5}{|c|}{ Phosphorus levels (P) kg ha ${ }^{-1}$} & \multicolumn{5}{|c|}{ Phosphorus levels (P) kg ha- ${ }^{-1}$} \\
\hline \multirow{2}{*}{ Nitrogen level } & \multicolumn{5}{|c|}{ Flower per plant } & \multicolumn{5}{|c|}{ flower yield $(q) h^{-1}$} \\
\hline & $0\left(\mathrm{P}_{0}\right)$ & $25\left(\mathrm{P}_{1}\right)$ & $50\left(\mathrm{P}_{2}\right)$ & $75\left(\mathrm{P}_{3}\right)$ & Average & $0\left(\mathrm{P}_{0}\right)$ & $25\left(\mathrm{P}_{1}\right)$ & $50\left(\mathrm{P}_{2}\right)$ & $75\left(\mathrm{P}_{3}\right)$ & Average \\
\hline $\mathrm{N}_{0^{-}} 0 \mathrm{~kg} \mathrm{~N} \mathrm{ha}{ }^{-1}$ & 37.73 & 40.96 & 42.50 & 42.06 & 40.81 & 54.26 & 61.23 & 67.13 & 65.50 & 62.03 \\
\hline $\mathrm{N}_{1-}-75 \mathrm{~kg} \mathrm{~N} \mathrm{ha}^{-1}$ & 41.46 & 45.06 & 48.03 & 47.43 & 45.50 & 62.43 & 67.40 & 72.00 & 70.46 & 68.07 \\
\hline $\mathrm{N}_{2}-100 \mathrm{~kg} \mathrm{~N} \mathrm{ha}^{-1}$ & 45.13 & 48.30 & 55.16 & 53.23 & 50.45 & 76.43 & 79.93 & 94.60 & 89.70 & 85.16 \\
\hline $\mathrm{N}_{3}-125 \mathrm{~kg} \mathrm{~N} \mathrm{ha}^{-1}$ & 44.90 & 47.90 & 53.93 & 52.53 & 49.81 & 75.66 & 78.83 & 90.50 & 87.10 & 83.02 \\
\hline \multirow{2}{*}{ Average } & 42.30 & 45.55 & 49.90 & 48.81 & & 67.20 & 71.85 & 81.05 & 78.19 & \\
\hline & $(\mathrm{N})$ & \multicolumn{2}{|c|}{$(\mathrm{P})$} & \multicolumn{2}{|c|}{ Interaction N X P } & $(\mathrm{N})$ & \multicolumn{2}{|c|}{$(\mathrm{P})$} & \multicolumn{2}{|c|}{ Interaction N X P } \\
\hline 'F' test & Sig. & \multicolumn{2}{|c|}{ Sig. } & \multicolumn{2}{|c|}{ Sig. } & Sig. & \multicolumn{2}{|c|}{ Sig. } & \multicolumn{2}{|c|}{ Sig. } \\
\hline $\mathrm{SE}(\mathrm{m}) \pm$ & 1.09 & \multicolumn{2}{|c|}{1.09} & \multicolumn{2}{|c|}{2.67} & 1.35 & \multicolumn{2}{|c|}{1.35} & \multicolumn{2}{|c|}{3.31} \\
\hline $\mathrm{CD}$ at $5 \%$ & 3.14 & \multicolumn{2}{|c|}{3.14} & \multicolumn{2}{|c|}{7.71} & 3.91 & \multicolumn{2}{|c|}{3.91} & \multicolumn{2}{|c|}{9.58} \\
\hline
\end{tabular}

Table 2: Effect of graded level of $\mathrm{N}$ and $\mathrm{P}$ on shelf life, vase life and oil content in calendula

\begin{tabular}{|c|c|c|c|c|c|c|c|c|c|c|c|c|c|c|c|}
\hline \multirow{3}{*}{ Nitrogen level } & \multicolumn{5}{|c|}{ Phosphorus levels (P) kg ha ${ }^{-1}$} & \multicolumn{5}{|c|}{ Phosphorus levels (P) kg ha-1 } & \multicolumn{5}{|c|}{ Phosphorus levels (P) kg ha ${ }^{-1}$} \\
\hline & \multicolumn{5}{|c|}{\begin{tabular}{|c|} 
Shelf life of flower (days) \\
\end{tabular}} & \multicolumn{5}{|c|}{ Vase life of flower (days) } & \multicolumn{5}{|c|}{ Oil content in flower $(\%)$} \\
\hline & $0\left(\mathrm{P}_{0}\right)$ & $25\left(\mathrm{P}_{1}\right)$ & $50\left(\mathrm{P}_{2}\right)$ & $75\left(\mathrm{P}_{3}\right)$ & Average & $0\left(\mathrm{P}_{0}\right)$ & $25\left(\mathrm{P}_{1}\right)$ & $50\left(\mathrm{P}_{2}\right)$ & $75\left(\mathrm{P}_{3}\right)$ & Average & $0\left(\mathrm{P}_{0}\right)$ & $25\left(\mathrm{P}_{1}\right)$ & $50\left(\mathrm{P}_{2}\right)$ & $75\left(\mathrm{P}_{3}\right)$ & Average \\
\hline $\mathrm{N}_{0-} 0 \mathrm{~kg} \mathrm{~N} \mathrm{ha}^{-1}$ & 1.13 & 1.23 & 1.33 & 1.26 & 1.24 & 2.93 & 3.10 & 3.46 & 3.36 & 3.21 & 0.22 & 0.23 & 0.24 & 0.24 & 0.23 \\
\hline $\mathrm{N}_{1}-75 \mathrm{~kg} \mathrm{~N} \mathrm{ha}^{-1}$ & 1.36 & 1.43 & 1.53 & 1.46 & 1.45 & 3.40 & 3.66 & 3.76 & 3.70 & 3.63 & 0.24 & 0.25 & 0.25 & 0.26 & 0.25 \\
\hline $\mathrm{N}_{2}-100 \mathrm{~kg} \mathrm{~N} \mathrm{ha}^{-1}$ & 1.66 & 1.73 & 1.86 & 1.80 & 1.76 & 3.76 & 3.80 & 4.00 & 3.86 & 3.85 & 0.25 & 0.26 & 0.29 & 0.28 & 0.28 \\
\hline $\mathrm{N}_{3}-125 \mathrm{~kg} \mathrm{~N} \mathrm{ha}^{-1}$ & 1.63 & 1.70 & 1.83 & 1.76 & 1.73 & 3.70 & 3.76 & 3.93 & 3.83 & 3.80 & 0.25 & 0.26 & 0.28 & 0.27 & 0.26 \\
\hline \multirow{2}{*}{ Average } & 1.45 & 1.52 & 1.64 & 1.57 & & 3.45 & 3.58 & 3.79 & 3.69 & & 0.24 & 0.25 & 0.27 & 0.26 & \\
\hline & $(\mathrm{N})$ & \multicolumn{2}{|c|}{$(\mathrm{P})$} & \multicolumn{2}{|c|}{ NXP } & $(\mathrm{N})$ & \multicolumn{2}{|c|}{ (P) } & \multicolumn{2}{|c|}{ NXP } & $(\mathrm{N})$ & \multicolumn{2}{|c|}{$(\mathrm{P})$} & \multicolumn{2}{|c|}{ NXP } \\
\hline 'F' test & Sig. & \multicolumn{2}{|c|}{ Sig. } & \multicolumn{2}{|c|}{ N.S. } & Sig. & \multicolumn{2}{|c|}{ Sig. } & \multicolumn{2}{|c|}{ N.S. } & Sig. & \multicolumn{2}{|c|}{ Sig. } & \multicolumn{2}{|c|}{ Sig.. } \\
\hline $\mathrm{SE}(\mathrm{m}) \pm$ & 0.03 & \multicolumn{2}{|c|}{0.03} & \multicolumn{2}{|c|}{0.08} & 0.04 & \multicolumn{2}{|c|}{0.04} & \multicolumn{2}{|c|}{0.11} & 0.004 & \multicolumn{2}{|c|}{0.004} & \multicolumn{2}{|c|}{0.01} \\
\hline $\mathrm{CD}$ at $5 \%$ & 0.09 & \multicolumn{2}{|c|}{0.09} & \multicolumn{2}{|c|}{-} & 0.13 & \multicolumn{2}{|c|}{0.13} & \multicolumn{2}{|r|}{-} & 0.012 & \multicolumn{2}{|c|}{0.012} & \multicolumn{2}{|c|}{0.03} \\
\hline
\end{tabular}

Table 3: Effect of graded level of N and P on total uptake of NPK by calendula (plant and flower)

\begin{tabular}{|c|c|c|c|c|c|c|c|c|c|c|c|c|c|c|c|}
\hline \multirow{3}{*}{ Nitrogen levels } & \multicolumn{5}{|c|}{ Phosphorus levels (P) kg ha'-1 } & \multicolumn{5}{|c|}{ Phosphorus levels (P) kg ha-1 } & \multicolumn{5}{|c|}{ Phosphorus levels (P) $\mathrm{kg} \mathrm{ha}^{-1}$} \\
\hline & \multicolumn{5}{|c|}{$\begin{array}{c}\text { Total uptake of } \mathrm{N} \text { by calendula plant and } \\
\text { flower }\left(\mathrm{kg} \mathrm{ha}^{-1}\right)\end{array}$} & \multicolumn{5}{|c|}{$\begin{array}{l}\text { Total uptake of } \mathrm{P} \text { by calendula } \\
\text { plant and flower }\left(\mathrm{kg} \mathrm{ha}^{-1}\right)\end{array}$} & \multicolumn{5}{|c|}{$\begin{array}{c}\text { Total uptake of } \mathrm{k} \text { by calendula plant } \\
\text { and flower }\left(\mathrm{kg} \mathrm{ha}^{-1}\right)\end{array}$} \\
\hline & $0\left(\mathrm{P}_{0}\right)$ & $25\left(\mathrm{P}_{1}\right)$ & $50\left(\mathrm{P}_{2}\right)$ & $75\left(\mathrm{P}_{3}\right)$ & Average & $0\left(\mathrm{P}_{0}\right)$ & $25\left(\mathrm{P}_{1}\right)$ & $50\left(\mathrm{P}_{2}\right)$ & $75\left(P_{3}\right)$ & Average & $0\left(\mathrm{P}_{0}\right)$ & $25\left(\mathrm{P}_{1}\right)$ & $\left|50\left(\mathrm{P}_{2}\right)\right| 7$ & $75\left(\mathrm{P}_{3}\right)$ & Average \\
\hline $\mathrm{N}_{0}-0 \mathrm{~kg} \mathrm{~N} \mathrm{ha}^{-1}$ & 79.46 & 85.67 & 89.04 & 95.52 & 87.42 & 42.63 & 48.34 & 52.15 & 56.74 & 49.96 & $102 . .91$ & 103.96 & 116.50 & 118.71 & 110.52 \\
\hline $\mathrm{N}_{1}-75 \mathrm{~kg} \mathrm{~N} \mathrm{ha}^{-1}$ & 86.79 & & 97.47 & & & 52.40 & 58.40 & & & & 114.77 & & & & \\
\hline $\mathrm{N}_{2}-100 \mathrm{~kg} \mathrm{~N} \mathrm{ha}^{-1}$ & 96.06 & & 103.13 & & & 56.50 & 65.31 & 69. & & & & .77 & 123.34 & & \\
\hline $\mathrm{N}_{3}-125 \mathrm{~kg} \mathrm{~N} \mathrm{ha}^{-1}$ & 103.60 & 107.57 & 111.69 & 119.80 & 110.68 & 66.38 & 70.94 & 75.27 & 84.62 & 75.30 & 124.76 & 126.76 & 130.66 & 135.80 & 129.50 \\
\hline \multirow[t]{2}{*}{ Average } & 91.46 & 95.80 & 100.33 & 107.03 & & 54.47 & 60.75 & 65.53 & 72.11 & & 115.24 & 117.11 & 122.48 & 125.39 & \\
\hline & $(\mathrm{N})$ & \multicolumn{2}{|c|}{$(\mathrm{P})$} & \multicolumn{2}{|c|}{ NX P } & $(\mathrm{N})$ & $(\mathrm{I}$ & P) & \multicolumn{2}{|c|}{ NXP } & $(\mathrm{N})$ & $(\mathrm{P})$ & & \multicolumn{2}{|c|}{ NXP } \\
\hline 'F' test & Sig. & \multicolumn{2}{|c|}{ Sig. } & \multicolumn{2}{|c|}{ Sig. } & Sig. & & & \multicolumn{2}{|c|}{ Sig. } & Sig. & & & \multicolumn{2}{|c|}{ Sig. } \\
\hline $\mathrm{SE}(\mathrm{m}) \pm$ & 0.90 & \multicolumn{2}{|c|}{0.90} & \multicolumn{2}{|c|}{2.21} & 0.78 & 0 . & 78 & \multicolumn{2}{|c|}{1.91} & 1.25 & & & \multicolumn{2}{|c|}{3.06} \\
\hline $\mathrm{CD}$ at $5 \%$ & 2.60 & \multicolumn{2}{|c|}{2.60} & \multicolumn{2}{|c|}{6.39} & 2.26 & 2. & 26 & \multicolumn{2}{|c|}{5.53} & 3.61 & 3.6 & 61 & \multicolumn{2}{|c|}{8.85} \\
\hline
\end{tabular}

\section{Yield parameter}

Significantly maximum number of flower plant ${ }^{-1}$ in treatment combination of $\mathrm{N}_{2} \mathrm{P}_{2}$ i.e. $100 \mathrm{~kg} \mathrm{~N}$ and $50 \mathrm{~kg} \mathrm{P} \mathrm{ha}^{-1}$ (55.16) which was followed by the treatment combination $\mathrm{N}_{3} \mathrm{P}_{2}$ i.e. $125 \mathrm{~kg} \mathrm{~N}$ and $50 \mathrm{~kg} \mathrm{P} \mathrm{ha}{ }^{-1}$ (53.93). However, minimum number of flower plant ${ }^{-1}$ in treatment combination $\mathrm{N}_{0} \mathrm{P}_{0}$ i.e. control treatment (37.73). Interaction effect of nitrogen and phosphorus might due to synergistic activities of all the growth nutrients which played active role in enlarging plats cell and tissues, consequently increased vegetative growth. Similar results were recorded by Sonawane et al., (2008) ${ }^{[8]}$ that, the application of nitrogen $200 \mathrm{~kg} \mathrm{ha}^{-1}$ with phosphorus $75 \mathrm{~kg} \mathrm{ha}^{-1}$ recorded maximum numbers of flowers plant ${ }^{-1}$ in china aster.

An application $100 \mathrm{~kg}$ nitrogen and $50 \mathrm{~kg}$ phosphorus ha ${ }^{-1}$ $\left(\mathrm{N}_{2} \mathrm{P}_{2}\right)$ had recorded maximum flower yield ha- ${ }^{-1}(94.60 \mathrm{q})$ 
which was followed with the treatment combinations $\mathrm{N}_{3} \mathrm{P}_{2}$ i.e. $125 \mathrm{~kg}$ nitrogen and $50 \mathrm{~kg}$ phosphorus ha ${ }^{-1}(90.50 \mathrm{q})$. However, minimum flower yield ha-1 $(54.26 \mathrm{q})$ was recorded in control treatment $\left(\mathrm{N}_{0} \mathrm{P}_{0}\right)$. From above finding, it was shown that, maximum flower yield $\mathrm{ha}^{-1}$ was recorded under the treatment $\mathrm{N}_{2} \mathrm{P}_{2}$ i.e. application $100 \mathrm{~kg}$ nitrogen and $50 \mathrm{~kg}$ phosphorus ha ${ }^{-1}$. Interaction effect of nitrogen and phosphorus might due to synergistic activities of all the growth nutrients which played active role in enlarging plats cell and tissues, consequently increased vegetative growth. Similar result were noted by Saman and Kirad (2013) that, the application of nitrogen $150 \mathrm{~kg} \mathrm{ha}^{-1}$ and phosphorus $80 \mathrm{~kg} \mathrm{ha}^{-1}$ had maximum flower yield ha-1 in calendula.

\section{Quality parameter}

An application $100 \mathrm{~kg} \mathrm{~N}$ and $50 \mathrm{~kg} \mathrm{P} \mathrm{ha}^{-1}$ had recorded maximum shelf life of calendula flower (1.86 days) which was followed with the treatment combinations $125 \mathrm{~kg} \mathrm{~N}$ and $50 \mathrm{~kg} \mathrm{P} \mathrm{ha}{ }^{-1}$ (1.83 days). However, minimum shelf life of calendula flower (1.13 days) was recorded in control treatment

Maximum vase life of flower was obseved in treatment combination N@100 kg ha-1 and P @ $50 \mathrm{~kg} \mathrm{ha}^{-1}$ (4.00 days) which was followed by $125 \mathrm{~kg} \mathrm{~N}$ and $50 \mathrm{~kg} \mathrm{P}^{-1}$ (3.93 days) However, Minimum vase life of flower was recorded in treatment combination $\mathrm{N}_{0} \mathrm{P}_{0}$ i.e. control treatment (2.93 days). The similar result were also observed by Navyashree et al., (2017) reported that, application of nitrogen $62.5 \mathrm{~g} \mathrm{plant}^{-1}$ with $25 \mathrm{~g} \mathrm{P}_{2} \mathrm{O}_{5}$ plant $^{-1}$ resulted significantly maximum vase life of flower in bird of paradise.

An application $100 \mathrm{~kg} \mathrm{~N}$ and $50 \mathrm{~kg} \mathrm{P} \mathrm{ha}{ }^{-1}$ had recorded maximum oil content in flower $(0.29 \%)$ which was followed with the treatment combinations $125 \mathrm{~kg} \mathrm{~N}$ and $50 \mathrm{~kg} \mathrm{P} \mathrm{ha}^{-1}$ $(0.27 \%)$. However, minimum oil content in flower $(0.22 \%)$ was recorded in control treatment. The similar result were also reported by Shirsat et al., (2015) ${ }^{[7]}$ that, application of nitrogen $180 \mathrm{~kg} \mathrm{ha}^{-1}$ with phosphorus $120 \mathrm{~kg} \mathrm{ha}^{-1}$ resulted significantly increase the oil per cent in marigold flower.

\section{Total uptake of calendula plant and flower}

Significantly maximum total uptake of $\mathrm{N}$ in calendula plant and flower was observed in treatment combination $\mathrm{N}_{3} \mathrm{P}_{3}$ i.e. $125 \mathrm{~kg} \mathrm{~N}$ and $75 \mathrm{~kg} \mathrm{P} \mathrm{ha}^{-1}\left(119.80 \mathrm{~kg} \mathrm{ha}^{-1}\right)$ which was followed by $\mathrm{N}_{3} \mathrm{P}_{2}$ i.e. $125 \mathrm{~kg} \mathrm{~N}$ and $50 \mathrm{~kg} \mathrm{P}^{-1}(111.69 \mathrm{~kg}$ $\left.\mathrm{ha}^{-1}\right)$. However, minimum total uptake of $\mathrm{N}$ in calendula plant and flower was recorded in treatment control $\left(79.46 \mathrm{~kg} \mathrm{ha}^{-1}\right)$. The results were similar with results updated by Nagaich et al., (2003) ${ }^{[3]}$ that, an application of $\mathrm{N} 120 \mathrm{~kg} \mathrm{ha}^{-1}$ and $\mathrm{P} 60 \mathrm{~kg}$ $\mathrm{ha}^{-1}$ had recorded maximum uptake of $\mathrm{N}$ by plant in marigold. Significantly maximum total uptake of $\mathrm{P}$ in calendula plant and flower was obseved in treatment combination $\mathrm{N}_{3} \mathrm{P}_{3}$ i.e. $125 \mathrm{~kg} \mathrm{~N}$ and $75 \mathrm{~kg} \mathrm{P} \mathrm{ha}^{-1}\left(84.62 \mathrm{~kg} \mathrm{ha}^{-1}\right)$ which was followed by $\mathrm{N}_{2} \mathrm{P}_{3}$ i.e. $100 \mathrm{~kg} \mathrm{~N}$ and $75 \mathrm{~kg} \mathrm{P} \mathrm{ha}^{-1}\left(79.12 \mathrm{~kg} \mathrm{ha}^{-1}\right)$. However, minimum total uptake of $\mathrm{P}$ in calendula plant and flower was recorded in control treatment (42.63 kg ha-1). From above results, it is shown that, the phosphorus uptake by different parts as well as total uptake, increased significantly with every step increase in the phosphorus levels. This might be attributed to increased availability and absorption of phosphorus from soil and also increased dry matter production. Similar finding were reported by Polara et al., (2014) ${ }^{[2]}$ updated that, an application of $\mathrm{N}$ at $200 \mathrm{~kg} \mathrm{ha}^{-1}$ and $\mathrm{P} 150 \mathrm{~kg} \mathrm{ha}^{-1}$ recorded maximum uptake of $\mathrm{P}$ by the plant in marigold cv. Pusa Narangi Gainda.
Significantly maximum total uptake of $\mathrm{K}$ in calendula plant and flower in treatment combination $\mathrm{N}_{3} \mathrm{P}_{3}$ i.e. $125 \mathrm{~kg} \mathrm{~N}$ and $75 \mathrm{~kg} \mathrm{P} \mathrm{ha}^{-1}$ (135.80 kg ha-1) which was followed by $\mathrm{N}_{2} \mathrm{P}_{3}$ i.e. $100 \mathrm{~kg} \mathrm{~N}$ and $75 \mathrm{~kg} \mathrm{P} \mathrm{ha-1} \mathrm{(130.66} \mathrm{kg} \mathrm{ha-1).} \mathrm{However,}$ minimum total uptake of $\mathrm{K}$ in calendula plant and flower was recorded in control treatment $\left(102.91 \mathrm{~kg} \mathrm{ha}^{-1}\right)$. The results were similar with the finding of Badole et al., (2015) ${ }^{[1]}$ that, the combined application of N@200 kg ha-1 and P@75 kg $\mathrm{ha}^{-1}$ significant increase in uptake of $\mathrm{K}$ in china aster.

\section{Conclusion}

The combine application of nitrogen @ $100 \mathrm{~kg} \mathrm{ha}^{-1}$ and phosphorus@50 kg ha ${ }^{-1}$ improve the yield parameter i.e., flower plant ${ }^{-1}$, fresh flower yield, quality parameter i.e. shelf life, vase life and oil content in calendula and combine application of nitrogen@125 kg ha ${ }^{-1}$ and phosphorus @ 75 $\mathrm{kg} \mathrm{ha}^{-1}$ significantly improve the total uptake of calendula plant and flower

\section{References}

1. Badole WP, Sanap PB, Vandana Kotangale, Pranali Bhaisare. Effect of nitrogen and phosphorus on nutrient uptake, yield and quality of china aster. J. Soil and Crops. 2015; 25(2):397-401.

2. Polora ND, Gajipara NN, Barad AV. Effect of nitrogen and phosphorus on nutrient content and uptake in different varieties of African marigold. The bioscan. 2014; 9(1):115-119.

3. Nagaich KN, Trivedi SK, Lekhi R. Effect of nitrogen and phosphorus on growth, flowering, yield and quality of marigold. Scientific Hort. 2003; 8:203-209.

4. Navyashree M, Munikrishnappa PM, Seetharamu GK, Krishna HC, Anil Kumar S, Dayamani KJ. Effect of major and micronutrients on yield, vase life, soil and leaf nutrient content of bird of paradise (Strelitzia reginae L.) Env. and Eco. 2017; 35(3B):2199-2204.

5. Panse VG, Sukhatme PV. Statistical methods for agricultural workers, ICAR, New Delhi, 1967, 155.

6. Saman SA, Kirad KS. Effect of nitrogen and phosphorus on seed yield parameters of calendula var. Touch of Red Mixture. Prog. Hort. 2013; 45(1):149-151.

7. Shirsat Priti R, Ommala D. Kuchanwar, Ingle SN, Zalte S, Abgad NP. Effect of integrated nutrient management on yield and quality of tuberose grown on vertisol. An Asian J. of soil Sci., 2015; 10(2):210-214.

8. Sonawane SP, Dabke DJ, Dodke SB, Rathod PK, Salvi VG. Effect of different levels of nitrogen, phosphorus and FYM on yield and quality of china aster (Callistephus chinensis L.) in lateritic soil of Konkan. J. Soils and Crop. 2008; 18(1):130-134. 